\title{
Colonisation potential of plantaricin-producing Lactobacillus plantarum SF9C and S-layer-carrying Lactobacillus brevis SF9B among gut microbiota
}

Katarina Butorac

Sveuciliste u Zagrebu Prehrambeno-Biotehnoloski Fakultet Martina Banic

Sveuciliste u Zagrebu Prehrambeno-Biotehnoloski Fakultet Jasna Novak

Sveuciliste u Zagrebu Prehrambeno-Biotehnoloski Fakultet

Andreja Leboš Pavunc

Sveuciliste u Zagrebu Prehrambeno-Biotehnoloski Fakultet

Ksenija Uroic

Sveuciliste u Zagrebu Prehrambeno-Biotehnoloski Fakultet

Nada Orsolic

Sveuciliste u Zagrebu Prirodoslovno-matematicki fakultet

Marina Kukolj

Sveuciliste u Zagrebu Prirodoslovno-matematicki fakultet

Slobodanka Radovic

IGA Technology Service

\section{Simone Scalabrin}

IGA Technology Service

Jurica Zucko

Sveuciliste u Zagrebu Prehrambeno-Biotehnoloski Fakultet

Antonio Starčevic

Sveuciliste u Zagrebu Prehrambeno-Biotehnoloski Fakultet

\section{Jagoda Suskovic}

Sveuciliste u Zagrebu Prehrambeno-Biotehnoloski Fakultet

\section{Blaženka Kos ( $\sim$ bkos@pbf.hr)}

Faculty of Food Technology and Biotechnology, University of Zagreb https://orcid.org/0000-0003-1711-316X

\section{Research}

Keywords: antibacterial activity, gut colonization, Lactobacillus, microbiota, plantaricin, S-layer

Posted Date: April 1st, 2020

DOI: https://doi.org/10.21203/rs.2.23400/v2 
License: (c) (i) This work is licensed under a Creative Commons Attribution 4.0 International License. Read Full License

Version of Record: A version of this preprint was published at Microbial Cell Factories on May 19th, 2020. See the published version at https://doi.org/10.1186/s12934-020-01365-6. 


\section{Abstract}

Background: The influence of an S-layer-carrying strain Lactobacillus brevis SF9B and a plantaricin-producing strain Lactobacillus plantarum SF9C on the gut microbiota composition was evaluated in the rats. Considering the probiotic potential of $L b$. brevis SF9B, this study aimed to examine the antibacterial activity of $L b$. plantarum SF9C and potential for their in vivo colonisation, which could be the basis for the investigation of their synergistic functionality.

Results: A plantaricin-encoding cluster was identified in Lb. plantarum SF9C, a strain which efficiently inhibited the growth of Listeria monocytogenes ATCC ${ }^{\circledR} 19111^{\mathrm{TM}}$ and Staphylococcus aureus 3048 . Contrary to the plantaricinproducing SF9C strain, the S-layer-carrying SF9B strain excluded Escherichia coli 3014 and Salmonella enterica serovar Typhimurium FP1 from adhesion to Caco-2 cells. Finally, DGGE analysis of the V2-V3 region of the 16S rRNA gene confirmed the transit of two selected lactobacilli through the gastrointestinal tract (GIT). Microbiome profiling via the Illumina MiSeq platform revealed the prevalence of Lactobacillus spp. in the gut microbiota of rats suggesting their colonisation potential in GIT.

Conclusion: The combined application of $\angle b$. plantarum SF9C and $L b$. brevis SF9B could influence the intestinal microbiota composition, which is reflected through the increased abundance of Lactobacillus genus, but also through altered abundances of other bacterial genera, either in the model of healthy or aberrant microbiota of rats. The obtained results contributed to the functional aspects of SF9C and SF9B strains which could be incorporated in the probiotic-containing functional foods and therefore have a beneficial influence on the gut microbiota composition.

\section{Background}

Lactobacillus strains are omnipresent in different ecological niches. The representative members dominate the microbiota of the sauerkraut and are under constant competition with other strains for nutrients and space (Collins et al., 2018). The antibacterial activity of Lactobacillus strains is an important factor for the pathogen elimination in the complex microbial communities. Lactobacillus strains able to produce bacteriocins may achieve a competitive advantage in the surrounding environment which represents an attractive approach in the terms of food biopreservation (Collins et al., 2018). Their applications are even expanding to the health point since bacteriocin production is recognised as an important probiotic trait and bacteriocins have even been proposed as alternatives to antibiotics (Chikindas et al., 2017; Mills et al., 2017). Bacteriocinogenic activity may contribute to the functionality of probiotics through direct inhibition of the pathogens. Moreover, bacteriocins help the survival of the producing strain and may act as quorum-sensing molecules in the intestinal environment. Previously, we monitored lactic acid bacteria (LAB) population during spontaneous fermentation of the Brassica oleracea var. capitata cultivar Varaždinski (Banić et al., 2018; Beganović et al., 2014; Beganović et al., 2011). At the onset of the spontaneous fermentation, LAB diversity was present, including Leuconostoc mesenteroides strains, while a restricted number of Lactobacillus species, mainly Lactobacillus plantarum, dominated in the latter stages (Beganović et al., 2014). Lb. brevis SF9B was isolated from the respective spontaneous fermentation. This strain showed desirable functional and technological properties largely influenced by S-layer proteins (SIps) which were detected by SDS-PAGE (Beganović et al., 2014) and identified by 2D electrophoresis followed by LC-MS analysis. SIps have a functional role in conveying increased survival of the respective strain in simulated GIT conditions and during freeze-drying. Moreover, the results indicate a prominent role of Slps in adhesion of SF9B strain to mucin, extracellular matrix (ECM) proteins, and particularly to Caco-2 cells (Banić et al., 2018). Besides SF9B, an 
autochthonous isolate SF9C was isolated at the final stage of spontaneous fermentation. This strain was identified as $L b$. plantarum, which is a prevalent species in sauerkraut fermentation, probably due to its competitiveness among autochthonous microbiota. Previous analysis of untreated supernatant of SF9C culture by a turbidimetric method revealed antibacterial activity towards some common pathogens (Beganović et al., 2014). Therefore, the aim of this study was to evaluate the competitive advantage potential of bacteriocin-producing $L b$. plantarum SF9C and S-layer-carrying $L b$. brevis SF9B against pathogens by in vitro and in vivo investigations. A possible bacteriocinogenic activity of SF9C strain against Gram-positive pathogens Listeria monocytogenes ATCC ${ }^{\circledR} 19111^{\mathrm{TM}}$ and Staphylococcus aureus 3048 was tested. The stimulation of bacteriocinogenic activity in SF9C strain was performed by its coculturing with common food pathogens. To observe whether this strain has a broader spectrum of the antibacterial activity, pathogen competition and competitive exclusion of Gram-negative Escherichia coli 3014 and Salmonella Typhimurium FP1 was also evaluated. Since preclinical evidence indicate that probiotic Lactobacillus strains may positively influence gut microbiota composition in different disorders followed by microbiota disturbance (Distrutti et al., 2014; Chen et al., 2016), the aim of this study was also to assess colonisation potential and the capacity of SF9C and SF9B strain to induce microbiome alterations in vivo, after joint application, either in healthy or $\mathrm{AlCl}_{3}$-exposed rats as a model of disturbed microbiota. PCR-DGGE and sequence analysis of faeces content were employed to investigate if $L b$. brevis SF9B and $L b$. plantarum SF9C have the potential for in vivo colonisation and the shift of the microbiota in the intestinal tract (IT) of rats.

\section{Results}

\section{Plantaricin-related genes andwhole genome sequences (WGS) of Lb. plantarum SF9C}

Plantaricin-related genes, $p / n A, p / n E$ and $p / n J$, were identified using PCR amplification, suggesting that SF9C genome could harbour a pln locus. Rapid Annotations using Subsystems Technology (RAST) of sequences obtained by Illumina MiSeq platform, and tblastn v.2.2.27 comparison of the assembled contigs with the sequences deposited in NCBI employed for WGS, identified SF9C as Lb. plantarum. This Whole Genome Shotgun project has been deposited at DDBJ/ENA/GenBank under the accession RHLZ0000000. The version described in this paper is version RHLZ 01000000. The genome sequence is composed of 3.26 million bp (Mb) and is divided into 14 contigs. The size of $\angle b$. plantarum SF9C genome of $3.2 \mathrm{Mb}$ is similar to that of the other members of the species. The number of coding sequences is 3,229 and the number of RNAs is 68 . According to the comparative genomic studies the estimated number of predicted protein-coding genes in Lactobacillus strains ranges from 1,700 to around 3,000 (Van Pijkeren and O'Tolle, 2013). The G+C content of the $L b$. plantarum SF9C genome is $44.4 \%$, which is similar to the other Lb. plantarum strains, e.g. Lb. plantarum WCFS1 (44.5\%) and Lb. plantarum ATCC 14917 (44.5\%) (Anukam et al., 2013). Subsystem category distribution of major Protein Encoding Genes (PEGs) for $L b$. plantarum SF9C as annotated by RAST is shown in Fig. 1. The pie chart is depicting the percentage distribution of 27 most abundant subsystem categories in strain SF9C. While the most of the PEGs were related to universal cell functions such as DNA replication, transcription, translation, ribosomal structure and biogenesis, protein turnover and chaperones, and transport and metabolism of carbohydrates and nucleotides, certain PEGs were associated to the specific categories of cellular defence mechanisms and secondary metabolites biosynthesis, transport, and catabolism which may be responsible for the antimicrobial phenotype of SF9C strain.

Given that SF9B and SF9C originate from the same microenvironment, their whole genomes were compared and the cluster dendrogram that reflects the diversity among strains was constructed. Single Nucleotide Polymorphism (SNP) hierarchical clustering based on WGS revealed that S-layer-carrying $L b$. brevis SF9B is grouped with another S-layer-expressing Lb.brevis (Fig. 2). Given that the phylogenetic distance between the strains was small, sauerkraut 
isolate $L b$. plantarum SF9C was grouped with SF15C strain, another isolated $\angle b$. plantarum strain from the same fermentation batch (Fig. 2).

Next, WGS data were exploited to identify potential genomic triggers that may be responsible for the antibacterial phenotype. The assembled contigs were compared with so far identified bacteriocins in the NCBI using the tblastn v2.2.27. Through functional annotation and analysis of the high-coverage contigs obtained through Illumina sequencing, plantaricin production was predicted for $L b$. plantarum SF9C. The genes involved in the bacteriocinogenic activity and their functions, which were also detected in the genomes of the other $L b$. plantarum strains, are listed in Supplementary Table 1. The genome sequence of $L b$. plantarum SF9C contains a cluster for biosynthesis of a putative plantaricin. In silico BAGEL4 analysis identified one area of interest (AOI) located at a contig 13. The pln locus of SF9C contains genes encoding their cognate immunity proteins, whose location is just downstream of the bacteriocin genes, as well as $A B C$ transporters, probably involved in the export of peptides with a double glycine leader (Fig. 3). Finally, homology-based three-dimensional (3D) structures of SF9C two-peptide plantaricins were predicted by the SWISS-MODEL. Properties of the chosen amino acid (aa) residues that form helix of each of the two plantaricins, PInJK and PInEF, were calculated by HeliQuest web server. Hydrophobic residues are shown in yellow, serine and threonine in purple, basic residues in dark blue, acidic residues in red, asparagine and glutamine in pink, alanine and glycine in grey, histidine in light blue and proline in green circles (Fig. 4).

\section{Antimicrobial activity of $L b$. plantarum SF9C after the cocultivation with pathogens}

Preliminary results regarding the antibacterial activity of $L b$. plantarum SF9C and $L b$. brevis SF9B clearly demonstrated the difference in the spectrum of antibacterial activity among two naturally coexisting strains (Table 1.). Interestingly, while grown cultures of both strains, SF9C and SF9B, demonstrated antibacterial activity against L. monocytogenes ATCC $® 19111^{\mathrm{TM}}$ and S. aureus 3048, CFS of the strain SF9B failed in the inhibition of the respective pathogens as evaluated by agar well-diffusion method (Table 1).

The antibacterial activity of the CFS of SF9C strain was partially inactivated after the treatment with proteinase $\mathrm{K}$ and after its exposure to high temperature of $100{ }^{\circ} \mathrm{C}$ during 30 minutes (Table 1 ). These findings confirm the presence of a substance with proteinaceous nature in CFS. Furthermore, the combined CFSs of both strains, SF9C and SF9B, in equal ratio, showed decreased antibacterial activity against $L$. monocytogenes ATCC ${ }^{\circledR} 19111^{\mathrm{TM}}$ and $S$. aureus 3048 which was expected since the CFS of S-layer-carrying SF9B strain did not demonstrate antibacterial activity against these two pathogens, and therefore negatively influenced on cumulative effect of both CFSs.

Similarly, the evaluation of the antibacterial activity of SF9C and SF9B against closely related LAB strains, showed that SF9C compared to SF9B, was more effective in the inhibition of the examined LAB strains, with the strongest effect observed against Enterococcus, moderate against Lactococcus and the weakest against Lactobacillus strains by agar well-diffusion method (data not shown). Antibacterial activity of the grown SF9C culture was additionally confirmed by agar spot test against pathogens (Table 1) and by cocultivation with the same pathogenic strains determined as bacteriocin-sensitive (Fig. 5). To assess the possibility to enhance the bacteriocin activity of Lb. plantarum SF9C, this strain was cocultivated with S. aureus 3048 and L. monocytogenes ATCC $^{\circledR} 19111^{\mathrm{TM}}$, respectively. The log CFU/ml values of the bacteriocin-sensitive strains, $S$. aureus 3048 and $L$. monocytogenes ATCC ${ }^{\circledR} 19111^{\text {TM }}$ were reduced to non-detectable levels after 48 and $24 \mathrm{~h}$, respectively, during the cocultivation with $\angle b$. plantarum SF9C (Fig. 5). Additionally, the antibacterial effect of $L$ b. plantarum SF9C, obtained by agar spot test, was significantly higher after growth in coculture with bacteriocin-sensitive test microorganisms:

with S. aureus 3048 after 8, 10 and 22 hours of incubation, whereas with L. monocytogenes ATCC ${ }^{\circledR} 19111^{\mathrm{TM}}$ after 22 , 
24 and 48 hours of incubation, showing that longer time of incubation is needed with L. monocytogenes ATCC $^{\circledR} 19111^{\text {TM }}$ than with S. aureus 3048 for the enhancing of plantaricin activity (Fig. 5). The obtained results indicate that the plantaricin activity of $L b$. plantarum SF9C was enhanced by the presence of the bacteriocinsensitive bacterial cells.

\section{Inhibition of pathogen adherence to Caco-2 cells by Lb. brevis SF9B}

The pathogen competition and exclusion assays by S-layer-carrying $L b$. brevis SF9B and $\angle b$. plantarum SF9C, on Caco-2 human intestinal cells were performed. Lb. brevis SF9B inhibited the adhesion of S. Typhimurium FP1 and especially E. coli 3014 (Table 2). Previous investigation revealed that SF9B strain had completely lost the adhesion ability to Caco-2 cell lines after the removal of the S-layer (Banić et al. 2018).

Lb. plantarum SF9C strain failed in adhesion to Caco-2 cells and therefore did not affect the exclusion of these Gram-negative pathogens (data not shown). On the contrary, strain SF9B inhibited S. Typhimurium FP1 adherence to the significant levels in competitive exclusion assay. In exclusion assay, Caco-2 cells exposed to $L b$. brevis SF9B before $S$. Typhimurium FP1 had significantly fewer Salmonella adhered to them $\left(4.708 \pm 0.014 \log _{10} \mathrm{CFU} / \mathrm{ml}\right)$ than Caco-2 cells exposed to $S$. Typhimurium FP1 alone $\left(6.825 \pm 0.099 \log _{10} \mathrm{CFU} / \mathrm{ml}\right)$. The competition assay revealed that Caco-2 cells incubated with $L b$. brevis SF9B had significantly fewer Salmonella cells adhered (5.613 \pm 0.135 $\log _{10} \mathrm{CFU} / \mathrm{ml}$ ) compared to Caco-2 cells infected with Salmonella alone. The inhibition effect was even stronger against $E$. coli 3014, where the high efficacy of preincubation for inhibiting an invasion of Caco-2 cells by $E$. coli 3014 was evident, with values of $2.209 \Delta \log _{10} \mathrm{CFU} / \mathrm{ml}$ when the pathogen was added subsequently (exclusion), or of $2.117 \Delta \log _{10} \mathrm{CFU} / \mathrm{ml}$ when $\angle$ b. brevis SF9B cells and pathogen were added simultaneously (competition) (Table 2).

\section{Influence of $L b$. brevis SF9B and $L b$. plantarum SF9C on gut microbiome composition}

The colonisation capacity of examined Lactobacillus strains and the gut microbiome composition after their transit through GIT was monitored in vivo on experimental animals. Since the aberrant microbiota differs from the microbiota of healthy subjects by the prevalence of undesirable species, the $\mathrm{AlCl}_{3}$-exposed rats was chosen as an animal model for microbiome dysbiosis because previous research showed that toxic metals such as aluminium (Al) have a direct negative impact on the gut microbiota in human and animals. Additionally, Lactobacillaceae, particularly $L$ b. plantarum, $L$ b. rhamnosus and $L$ b. brevis, were able to bind and remove toxic metals (Yu et al. 2016). A recent study by Tian et al. (2017) also suggests the potential of the $L b$. plantarum strain to alleviate the aluminium-induced brain injuries in mice. Therefore, the potential of $\angle b$. plantarum SF9C and $\angle b$. brevis SF9B to compete among microbiota of $\mathrm{AlCl}_{3}$-exposed rats was investigated. The acetylcholinesterase (AChE) activity was assessed in the brain tissue homogenates to monitor the possible influence of $\mathrm{AlCl}_{3}$ treatment in the rats. The AChE activity and histopathological and immunohistochemical analyses of the brain have shown that the number of plaques and the AChE activity were significantly higher in the brains of the AT group, compared to that of the control group $(\mathrm{P}<0.05)$ (personal communication by Ledinski et al. 2017). According to the result, the neuropathological changes were observed in the $\mathrm{AlCl}_{3}$-exposed rats. Diffuse plaques, also called benign plaques, occurred much earlier than the neuritic plaques in the cerebellum. In the treatments, cerebellum of the AT rats was negative on the AT8 marker, but positive on 4G8 and Iba1 marker (Supplementary Fig. 1). The value of AChE in the control group was lower (Min-Max value 1.2 to 1.58 moles of substrate hydrolyzed/min/mg protein) compared to the AT group (Min-Max value from 1.38 to 2.4 moles of substrate hydrolyzed/min/mg protein). Further, the analysis of faecal microbiota of rats by Illumina MiSeq sequencing revealed that across all, control or $\mathrm{AlCl}_{3}$-exposed groups 
(calculated as mean values from all the experiments), the dominant phyla were Firmicutes and Bacteroidetes, which respectively made up $63 \%(62.35 \pm 5.40 \%)$ and $22 \%(21.76 \pm 6.20 \%)$ of total abundance, with lower contributions from Actinobacteria (1.65 $\pm 0.73 \%$ ) and Proteobacteria (1.84 $\pm 0.58 \%$ ) (Fig. 6a). The Firmicutes and Bacteroidetes phyla accounted for more than $85 \%$ of total sequences, similar to previous findings in the gut microbiota of rats. However, phylum- through genus-wide differences in bacterial abundance were observed among the two groups. In the microbiome of $\mathrm{AlCl}_{3}$-exposed rats the abundance of Firmicutes and Actinobacteria decreased, while the abundance of Bacteroidetes increased compared to the control group. At the class level, the most abundant for all groups were Bacilli, Clostridia and Bacteroidia (Fig. 6b). Bifidobacterium was also consistently detected through the samples (Fig. 6a). Since our main goal was to evaluate the survival and colonisation potential of the two Lactobacillus strains in the model of healthy, but also in experimental animals with disturbed microbiota, the focus was on the evaluation of Lactobacillus abundance. The abundance in Lactobacillus sp. was observed in all treated rat groups, implying good adaptation of SF9B and SF9C to the GIT, especially since these two strains are not of an intestinal, but sauerkraut origin. The gut microbiome analysis revealed taxonomic differences in gut microbiota composition influenced by Lactobacillus treatments. The culture-independent PCR-DGGE approach was applied to verify the presence of lactobacilli in the gut microbiota of faecal samples among rats before and the treatment with SF9B nad SF9C strains (Fig. 7). The cultivation on selective agar plates revealed the presence of presumptive Lactobacillus in the faeces of the control group at $5.6 \times 10^{7} \mathrm{CFU} / \mathrm{ml}$ and $\mathrm{AlCl}_{3}$ rats at $1.99 \times 10^{8} \mathrm{CFU} / \mathrm{ml}$, respectively the $10^{\text {th }}$ day after Lactobacillus treatment, which is in correlation with the results obtained by the Illumina MiSeq sequencing. DGGE analysis was employed to verify which Lactobacillus strains are potentially responsible for the observed higher Lactobacillus spp. abundance levels in the microbiota of Lactobacillus-treated rats. DGGE of DNA fragments obtained by PCR amplification of the V2-V3 region of the 16S rRNA gene implied the presence of both Lactobacillus strains in the faeces of treated rats since their DNA fragment coincided with the 16S DNA fragment generated from the pure culture of $\angle b$. brevis SF9B and $L b$. plantarum SF9C (Fig. 7). The inoculation of the healthy rats with Lactobacillus strains led to the appearance of a new 16S DNA fragment in the DGGE profile of the sample performed from the healthy rat the $3^{\text {rd }}$ day after Lactobacillus treatment, which corresponded to Lactobacillus reuteri. Interestingly, the results of microbiota analysis, at the species level, have shown the presence of $L b$. reuteri and $L b$. brevis as well. Furthermore, in a DGGE profile of the healthy rat, an intensive band was consistently detected, assigned after the sequencing and BLAST search as $L b$. animalis, while the $3^{\text {rd }}$ day after Lactobacillus treatment, a faint band appeared corresponding to Lactobacillus intestinalis strain (Fig. 7).

\section{Discussion}

Functional genomics in probiotic research has facilitated the characterisation of candidate Lactobacillus strains. Bacteriocin production is a desirable trait of probiotic strains (Hegarthy et al., 2017). Herein, Lb. plantarum SF9C genome sequence was determined using a WGS assembly approach, with a focus on the characterisation of the plantaricin locus. The whole genome sequencing confirmed the presence of the plantaricin ( $p / n$ ) loci in SF9C strain. plnE and plnF genes that encode for bacteriocin precursor peptide and the $p / n A$ which encodes induction factor and individual gene plnJ were also detected by PCR. Plantaricin EF (PInEF) and plantaricin JK (PInJK) have already been described in certain $L b$. plantarum strains as two-peptide bacteriocins. These compounds are biosynthesised as prepeptides and are cleaved off during the transport to the cell surface to become active peptides whose activity is dependent on the complementary action of the two peptides PInE/PInF i.e. PInJ/PInK (Diep et al., 2009).

Predicted 3D structures of two SF9C plantaricins by SWISS homology modelling showed sequence similarity with the structures of PInJK and PInEF plantaricins, obtained by Rogne et al. (2009) and Fimland et al. (2008), respectively. 
Bacteriocin activity together with competition for limited nutrients, competitive exclusion, and the stimulation of mucosal immunity could enhance intestinal health (Dobson et al., 2012). Here the antibacterial activity of the $L b$. plantarum SF9C against L. monocytogenes $\mathrm{ATCC}^{\circledR} 19111^{\mathrm{TM}}$ and S. aureus 3048 was explored. $L$ b. plantarum SF9C drastically decreased the $\mathrm{pH}$ value $(3.86 \pm 0.04)$ after overnight growth due to the lactic acid production $(2.25 \pm$ $0.24 \% \mathrm{v} / \mathrm{v}$ ) which creates unfavourable local microenvironment for pathogenic bacteria. The mechanisms of the antibacterial activity of SF9C strain are multifactorial and include the inhibition by produced lactic acid, but also by the activity of potential SF9C-produced plantaricin, especially since the inhibition was alleviated after CFS proteinase $\mathrm{K}$ and boiling treatment. L. monocytogenes ATCC ${ }^{\circledR} 19111^{\mathrm{TM}}$ and S. aureus 3048 possess several mechanisms to combat the challenges posed by acidic environments and therefore can tolerate low $\mathrm{pH}$ values. This claim was supported by the finding that the $L b$. plantarum SF9C strain demonstrates antibacterial activity against L. monocytogenes ATCC ${ }^{\circledR} 19111^{\mathrm{TM}}$ and $S$. aureus 3048 contrary to $L b$. brevis SF9B, which failed in the inhibition of respective pathogens, even though it is an effective lactic acid producer. Additionally, L. monocytogenes and $S$. aureus were deliberately chosen since these foodborne Gram-positive pathogens contaminate the wide range of fermented foods, although the $\mathrm{pH}$ value in these food matrices is low due to the metabolic activity of a spontaneously present population of LAB. Therefore, it was hypothesized that the potential plantaricin is involved in the antibacterial activity towards L. monocytogenes and $S$. aureus. Since one strategy to achieve the expression of otherwise silenced bacteriocins is the induction of their biosynthesis by growth in cocultures (Chanos and Mygind, 2016; Maldonado-Barragán et al., 2013; Kos et al., 2011), the potential to enhance plantaricin antibacterial activity by cocultivation of $L$ b. plantarum SF9C with S. aureus 3048 and L. monocytogenes ATCC ${ }^{\circledR} 19111^{\text {TM }}$ was studied. Antibacterial activity was initially detected after $10 \mathrm{hrs}$ of incubation in the early exponential phase of the pathogen growth. The highest antibacterial activity was marked after $24 \mathrm{hrs}$ in the late exponential phase of $L$. monocytogenes ATCC ${ }^{\circledR} 19111^{\mathrm{TM}}$ and after $48 \mathrm{hrs}$ for S. aureus 3048 . This is supported by the results of MaldonadoBarragán et al. (2013) who suggested that the induction of bacteriocin production by means of coculturing with specific bacterial strains is a common feature among $L b$. plantarum species. Since $L$. monocytogenes tolerates a broad $\mathrm{pH}$ range, it can be speculated that the SF9C plantaricin activity was potentially enhanced in the presence of L. monocytogenes ATCC ${ }^{\circledR} 19111^{\mathrm{TM}}$ and the obtained antilisterial effect of SF9C could be assigned to the potential plantaricin activity. This is in agreement with the feature of Lactobacillus bacteriocins which are mostly active towards Gram-positive bacteria.

Since SF9C did not prevent pathogen exclusion on the Caco-2 cells, the potential of S-layer-carrying $L b$. brevis SF9B, to exclude enteric pathogens was tested. Slps may act as mediators of bacterial adhesion and as such may contribute to the antibacterial activity against the pathogens with whom the S-layer-carrying strain competes for the same adhesion sites (Uroić et al., 2016; Hynönen et al., 2014; Taverniti et al., 2013). In our previous paper, SF9B strain exhibited the strongest coaggregation with E. coli 3014 and S. Typhimurium FP1 and the removal of SIps negatively affected its coaggregation ability. The results of this study revealed that $L b$. plantarum SF9C did not compete and exclude the pathogens from the Caco-2 cells, while S-layer-carrying SF9B strain demonstrated significant levels $(\mathrm{P}<0.01)$ of exclusion capacity against both $E$. coli 3014 and $S$. Typhimurium FP1, respectively. Additionally, the competitive capacity of SF9B strain was also obtained against both Gram-negative pathogens, but more effective against E. coli 3014. Nevertheless, Lb. brevis SF9B strain may prevent and exclude E. coli 3014 and S. Typhimurium FP1, exhibited considerable coaggregation capacity (Banić et al., 2018), even after only 1-hour incubation on Caco- 2 cells in the respective experiment. The coaggregation enables lactobacilli to manipulate a microenvironment around the pathogenic bacteria and to inhibit their growth in the gut by secreting antimicrobial substances at their very close proximity. The results suggest that $L b$. brevis SF9B competed more efficiently against E. coli 3014 than S. Typhimurium FP1 since the mechanisms of competition and exclusion differ and are highly 
specific for each pathogen. Combining plantaricin producer $L b$. plantarum SF9C with S-layer-carrying $L b$. brevis SF9B offers an effective strategy to suppress L. monocytogenes ATCC ${ }^{\circledR} 19111^{\mathrm{TM}}$, S. aureus 3048 , E. coli 3014 and $S$. Typhimurium FP1 since the joint application of these potential probiotic strains could result in a broader spectrum of antibacterial activity. One drawback of the direct application of bacteriocins to a food product is that the loss of activity occurs over time due to enzymatic degradation and interactions with food components such as proteins and lipids (Hartmann et al., 2011). Here it was suggested the potential application of the plantaricin-producing cells of $L b$. plantarum SF9C, which can act synergistically with $L b$. brevis SF9B, to eliminate common pathogens. $L b$. brevis SF9B is a non-producing bacteriocin strain, but whose genome contains $p / n /$ gene, encoding the bacteriocin immunity protein (Banić et al., 2018). Both strains, SF9B and SF9C have shown tolerance to harsh conditions of GIT because their relative survival rate displayed only a 2-log and 3-log decrease in CFU/ml, respectively, under the conditions mimicking the GIT (Banić et al., 2018; Beganović et al., 2014). The cooperation of coexisting Lactobacillus strains can be also exploited to control bacterial infection for the reestablishment of the disturbed gut microbiota associated with certain diseases (Dicks et al., 2018). Therefore, the potential of plantaricin-producing SF9C and S-layer-carrying SF9B strain to compete among healthy or disturbed gut microbiota was examined after their application to the healthy and $\mathrm{AlCl}_{3}$-exposed rats. $\mathrm{AlCl}_{3}$-exposure can cause a variety of adverse physiological effects in humans and animals, including disturbance of gut microbiota (Chen et al., 2016; personal communication Ledinski et al., 2017). After Lactobacillus treatment of rats, the changes in intestinal microbiota composition were observed, not only in the abundance of Lactobacillus genus but also in the abundance of other bacterial genera. According to microbiome analysis, Blautia genus was not detected in healthy rats but was identified in the $\mathrm{AlCl}_{3^{-}}$ exposed rats in which its ratio decreased $3^{\text {rd }}$ and $10^{\text {th }}$ day after the Lactobacillus application. The ratio of Bacteroides and Phascolarctobacterium genera before the Lactobacillus treatment was higher in the $\mathrm{AlCl}_{3}$-exposed rats compared to healthy reats, but $3^{\text {rd }}$ day after the Lactobacillus administration the ratio of these genera was reduced in $\mathrm{AlCl}_{3}$-exposed rats and increased in healthy rats, compared to ratio of these genera before Lactobacillus application. Furthermore, the abundance of the Bifidobacterium genus remained unchanged, before and after the Lactobacillus treatment, in both the healthy and the $\mathrm{AlCl}_{3}$-exposed rats. Clostridium and Adlercruetzia genera were evenly present in both groups, before the Lactobacillus application, while the $3^{\text {rd }}$ and $10^{\text {th }}$ day after Lactobacillus application the ratio of Adlercruetzia genus decreased in both groups of rats and the ratio of Clostridium genus decreased only in $\mathrm{AlCl}_{3}$-exposed rats. An abundant prevalence of Lactobacillus spp. was observed in the microbiota of the Lactobacillus treated rats, even $10^{\text {th }}$ day after the Lactobacillus application, compared to the microbiota of the healthy rats. This increased abundance of the Lactobacillus genus possibly reflects an adaptation of $L b$. plantarum SF9C and $\angle b$. brevis SF9B in GIT as evaluated by PCR-DGGE. However, besides allochthone lactobacilli SF9B and SF9C, PCR-DGGE indicated a presence of other commensal lactobacilli, suggesting the possible impact of applied Lactobacillus strains on the competitive ability of autochthonous strains. The obtained results emphasise the influence of applied Lactobacillus strains on rat microbiota composition, which will be valuable for further experiments on more experimental animals, in order to investigate interactions of specific treats of Lactobacillus strains, such as SIps and bacteriocin production, with faecal microbiota composition. Further studies are needed to better understand the probiotic effects of these two strains on a healthy and disturbed gut microbiome composition and function, and the possible impacts on other parameters important in alleviating $\mathrm{AlCl}_{3}-$ induced toxicity in host.

\section{Conclusion}


The results of this research supported an enhanced functionality potential of the joined application of SF9C and SF9B strains in vivo. The cooperation between two strains could result in a facilitated adhesion of $L b$. plantarum SF9C due to the competitive pathogen exclusion by coexisting $L b$. brevis SF9B. Simultaneously, SF9B could benefit from the improved colonisation due to plantaricin production by Lb. plantarum SF9C, resulting in a broader spectrum of antibacterial activity of the coculture against the pathogens. The plantaricin- and S-layer-expressing Lactobacillus strains could be a promising probiotic candidates for an application in functional food and for the treatment of different disorders linked with a dysbiosis of gut microbiota, which require further investigation.

\section{Materials And Methods}

\section{Bacterial strains, culture media and cultivation conditions}

Bacterial strains and cultivation conditions, used in this study, are listed in Table 3.

S-layer-carrying $L b$. brevis SF9B was previously characterised by Banic et al. (2018). Strains are deposited in the Culture Collection of the Laboratory of Antibiotic, Enzyme, Probiotic and Starter Culture Technologies, Faculty of Food Technology and Biotechnology, University of Zagreb (CIM-FFTB) and are maintained as frozen stocks at -80 ${ }^{\circ} \mathrm{C}$ in appropriate medium supplemented with $15 \%$ (v/v) glycerol.

\section{Human cell line, culture medium and cultivation conditions}

Enterocyte-like Caco-2 cells were donated by the Ruđer Bošković Institute, Zagreb, Croatia. Caco-2 cells were grown as monolayer cultures in RPMI 1640 medium (GIBCO, USA), supplemented with $15 \%$ of the fetal bovine serum (GIBCO, USA) and $4500 \mathrm{mg} / \mathrm{l}$ of glucose. Cells were grown up to confluence at $37^{\circ} \mathrm{C}$ and $5 \%$ of $\mathrm{CO}_{2}$ in T-flasks, trypsinised and seeded into 24-multiwell plates. Prior to experiments, cells reached sub-confluence.

\section{DNA isolation and PCR analysis}

Total genomic DNA, both for PCR analysis of the bacteriocin genes or WGS, was extracted according to the method of Leenhouts et al. (1990) with minor modifications. The purity and concentration of the extracted DNA were then determined by using a BioSpec-Nano spectrophotometer (Shimadzu, Kyoto, Japan) and the extracted DNA was stored at $-20^{\circ} \mathrm{C}$. PCR screening for the prevalence of bacteriocin structural genes was performed with primers listed in Ben Omar et al. (2008). Therefore, amplification of DNA fragments was performed in $50 \mu$ reaction mixtures containing $25 \mu$ l of Emerald Amp MAX HS PCR Mastermix Premix (TaKaRa, Ohtsu, Japan), $200 \mathrm{nmol} / \mathrm{l}$ of each oligonucleotide primer, $300 \mathrm{ng}$ of DNA template and EmeraldAmp $\mathrm{dH}_{2} \mathrm{O}$. A negative control, which contained all reagents except the DNA template, was used to detect contamination or non-specific amplification. The amplification was carried out in an Eppendorf Mastercycler personal thermal cycler (Eppendorf, Germany) using the conditions described by the Ben Omar et al. (2008). PCR-amplified products were separated by electrophoresis in a $1 \%$ agarose gel, stained with ethidium bromide $(0.5 \mu \mathrm{g} / \mathrm{ml})$ and visualised on a MiniBIS Pro transilluminator (DNR Bio-Imaging Systems Ltd., Jerusalem, Israel) at $254 \mathrm{~nm}$ and images were captured by the GelCapture software version 7.1 (DNR Bio-Imaging Systems Ltd., Jerusalem, Israel).

\section{Whole genome sequencing and identification of genesencodingbacteriocins}

Genomic DNA was prepared according to Frece et al. (2009). Genome sequencing was done using a paired-end approach as essentially described in Banić et al. (2018). Briefly, the Nextera DNA Library Preparation Kit (Illumina, San Diego, CA, USA) was used to construct a library. The library was processed with the Illumina cBot and 
sequenced on the MiSeq2500 (Illumina, San Diego, CA) pair-end with 300 cycles per read. Contigs were classified as belonging to $L$ b. plantarum when obtaining the best blastn v2.2.27 hit (Altschul et al., 1990) in the NCBI nt database. RAST server, which identifies protein-encoding, rRNA and tRNA genes, assigns functions to the genes, and predicts which subsystems are represented in the genome (Aziz et al., 2008), was used for the annotation, and the distribution and categorization of all sequenced genes. The assembled contigs were compared with so far identified bacteriocins in the NCBI using the tblastn v2.2.27. To further supplement the annotation, BAGEL4 sofware was used to predict genes related to bacteriocin synthesis (van Heel et al., 2018). The input file was the genome sequence of $L b$. plantarum SF9C in a fasta file. Conserved genes associated with the bacteriocin synthesis were retrieved using the RAST server (Aziz et al., 2008). Additionally, WGS were pairwise aligned with "run-mummer3" to detect alignments and SNPS. The plot was computed with R package hclust, based on SNP frequency. Further, the 3D structure homology modelling was done using the SWISS-MODEL server (https://swissmodel.expasy.org/) based on the alignment of the amino acid sequences of the core peptides, generated from BAGEL4 software. Additionally, helix properties of each two plantaricin were calculated using heliQuest web server (Gautier et al., 2008).

\section{In vitro assays}

\section{Testing of antimicrobial activity}

The antimicrobial activity of the overnight grown culture of $L b$. plantarum SF9C and $L b$. brevis SF9B strains against L. monocytogenes ATCC ${ }^{\circledR} 19111^{\text {TM }}$ and $S$. aureus 3048 was tested by agar spot test and well-diffusion method. The agar spot test was performed according to Leboš Pavunc et al. (2013). The ratio of the inhibition diameter (ID) to the spot culture diameter (CD) was calculated to determine the effective inhibition ratio (EIR) of SF9C strain: ((IDCD)/CD). Furthermore, the agar well-diffusion method, previously described by Kos et al. (2008) was applied for the analysis of antimicrobial activity of the cell free supernatant (CFS). CFS was recovered by centrifugation, filtered through a $0.22 \mu \mathrm{m}$ sterile filter (Millipore Corporation, Billerica, MA, USA) and concentrated up to 5-fold in an Amicon cell concentrator (Amicon, Beverly, MA, USA) equipped with a selective (10 kDa) membrane. The proteinaceous nature of potential inhibitory compounds in CFS was examined by treatment with Proteinase K (Invitrogen, Carlsbad, CA, USA) at a concentration of $1 \mathrm{mg} / \mathrm{ml}$ during $2 \mathrm{~h}$ at $37^{\circ} \mathrm{C}$ and by heating the samples at $100{ }^{\circ} \mathrm{C} / 30 \mathrm{~min}$, according to Elayaraja et al. (2014). Statistical analysis was carried out using ANOVA and the results are reported as mean values of three individual experiments \pm standard deviation. One-way analysis of variance (ANOVA) and Tukey tests were performed using VassarStats software to determine significant group differences and means were considered as statistically significant if $\mathrm{P}<0.05$.

\section{Evaluation of the antibacterial activity after cocultivation with the targeted pathogens}

The influence of cocultivation of $L$ b. plantarum SF9C with L. monocytogenes ATCC ${ }^{\circledR} 19111^{\text {TM }}$ and S. aureus 3048 on bacteriocin activity of SF9C strain was performed according to Kos et al. (2008) with slight modifications. The number of viable cells was determined by spot-plate method using the corresponding selective media for each strain: MRS for lactobacilli; Baird-Parker (Oxoid, Hampshire, UK) for S. aureus and ChromoBio (Biolab Diagnostic Laboratory, Budapest, Hungary) for L. monocytogenes, in 2 hour intervals during the first 10 hours, and after 22, 24 and $48 \mathrm{~h}$ of the incubation. Plates were incubated for 24 hours at $37^{\circ} \mathrm{C}$ and the number of viable cells was expressed as log CFU/ml. Also, during the experiment, the antibacterial activity of SF9C strain, in monoculture and coculture, was tested by agar spot test as described above. Experiments were conducted in triplicate and values 
were expressed as the mean \pm standard deviation. One-way analysis of variance (ANOVA) and Tukey tests were performed for statistical analysis.

\section{Pathogen competition and exclusion assay by $L b$. brevis SF9B and $L b$. plantarum SF9C on Caco-2 cell line}

For exclusion and competition assay experiments, Caco-2 cells were routinely grown in 24-well culture plates until confluent differentiated monolayers were obtained. Cellular monolayers were carefully rinsed three times with PBS ( $\mathrm{pH}$ 7.4) before addition of the bacterial cells. Two separate protocols were followed to assess the ability of viable lactobacilli strains to inhibit E. coli 3014, S. Typhimurium FP1 adhesion to Caco-2 cells. For both assays, Lactobacillus strains and pathogens were routinely cultivated; the cells were harvested and prepared in PBS (pH 7.4) to reach $\mathrm{A}_{620}=1$ (approximately $1 \times 10^{9} \mathrm{CFU} / \mathrm{ml}$ ). The competition assay was performed according to the procedure described by Uroić et al. (2016) with few modifications. Lactobacilli and pathogens were co-incubated with Caco- 2 monolayer for $1 \mathrm{~h}$. For exclusion assays, Lactobacillus strains were cultured with Caco-2 monolayer for $1 \mathrm{~h}$. Following $1 \mathrm{~h}$ incubation, Caco-2 monolayers were gently washed three times with PBS (pH 7.4); pathogens were added and incubated for another $1 \mathrm{~h}$. A $1.0 \mathrm{ml}$ aliquots of the monospecies cultures of pathogenic bacteria together with $1.0 \mathrm{ml}$ of EMEM per well were used as the controls in both assays. In all the above treatments, postincubation removal of the non-adhered bacterial cells was executed by removing the bacterial suspension and washing the Caco-2 monolayers three times with PBS ( $\mathrm{pH} 7.4)$. The Caco-2 cells were then lysed by addition of $0.25 \%$ (v/v) Triton X-100 (AppliChem, Darmstadt, Germany) solution at $37^{\circ} \mathrm{C}$ for $10 \mathrm{~min}$ in order to collect the adherent bacterial cells, and the total numbers of viable adhering Lactobacillus, E. coli and $S$. Typhimurium were determined by spot-plate method on MRS, Rapid (Biorad, Dubai, United Arab Emirates) and XLD (Biolife, Milano, Italy) agar plates, respectively. The efficiency of pathogen exclusion of Lactobacillus strains was assayed in three biologically independent experiments each with three replicates.

\section{In vivo animal trial}

\section{Preparation of $L b$. brevis SF9B and $L b$. plantarum SF9C strains and administration to rats}

Bacterial cultures $\angle b$. brevis SF9B and $\angle b$. plantarum SF9C were grown in $5 \mathrm{ml}$ of MRS broth at $37^{\circ} \mathrm{C}$ under anaerobic conditions until the OD value reached 1.0 at $620 \mathrm{~nm}$. The as-prepared cultures were mixed in 1:1 (v/v) ratio and inoculated (4\%) in $50 \mathrm{ml}$ of MRS broth. After overnight incubation at optimal conditions, the cells were harvested by centrifugation at $5000 \mathrm{~g}$ for $10 \mathrm{~min}$, suspended in saline solution and the presence of both strains was microscopically examined. The bacteria suspensions were prepared daily to ensure viability and the CFU was controlled to maintain strictly the number of CFU administered by a rat as it is described in the next chapter.

\section{Experimental animals}

Three-months-old male highly inbred Y59 strain rats, weighing 200 to $250 \mathrm{~g}$, (http://www.informatics.jax.org/external/festing/rat/docs/Y59.shtml), obtained from our breeding within the Department of Animal Physiology, Faculty of Science, University of Zagreb, were used in this study. The animals were maintained under a 12/12-h light-dark cycle with free access to food and water and standard housing conditions (room temperature around $25^{\circ} \mathrm{C}$ and $60 \%$ humidity). They were fed a standard laboratory diet (4 RF 21 , Mucedola, Settimo Milanese, Italy) and tap water ad libitum. Maintenance and care of all experimental animals were carried out according to the guidelines in force in the Republic of Croatia (Law on the Welfare of Animals, NN135/06 and NN37/13) and in accordance with EU Directive 2010/63/EU for animal experiments (OJEU, 2010) and carried out in compliance with the Guide for the Care and Use of Laboratory Animals, DHHS Publ. \# (NIH) 86- 
123. The experimental procedure was approved by the Bioethics Committee of the Faculty of Science, University of Zagreb, Croatia (No. HR-POK-012).

\section{Rat study design and sample collection}

Male rats belonging to the $Y 59$ inbred strain were randomly divided into 2 equally sized trial groups and housed three per cage in stainless-steel cages, under the same controlled conditions. The rats were treated daily for five consecutive days with a single dose $\left(3 \times 10^{9} \mathrm{CFU} / \mathrm{ml}\right)$ of $L b$. brevis SF9B and $L$ b. plantarum SF9C strains suspended in saline solution, starting $24 \mathrm{~h}$ after the last treatment as follows: (a) first trial group represented a model of induced aluminium toxicity which was established by intraperitoneally injecting $\mathrm{AlCl}_{3}(10 \mathrm{mg} / \mathrm{kg})$ and D-galactose (60 mg/kg) as described by Ulusoy et al. (2015) and (b) second group served as healthy (control) group and was injected comparatively with saline solution in the same manner. No side effects were reported following Lactobacillus administration. In order to evaluate the AchE activity, which requires a brain sample, rats had to be sacrificed. Before the sacrifice rats were anesthetized using a mixture of ketamine (Narketan ${ }^{\circledR} 10$, Vetoquinol $A G$, Belp Bern, Switzerland) at dose of $75 \mathrm{mg} / \mathrm{kg}$ with xylazine (Xylapana ${ }^{\circledR}$ Vetoquinol Biowet Sp., Gorzow, R. Poland) at dose of $10 \mathrm{mg} / \mathrm{kg}$. The intestinal mucosal content from each sacrificed rat was scraped and specimens were kept frozen at $-80{ }^{\circ} \mathrm{C}$ until the analysis. The brain was removed and frozen at $-80^{\circ} \mathrm{C}$ or kept in buffered formaldehyde until the analysis. The brain tissue homogenates were used to assess acetylcholinesterase (AChE) activity by colorimetric method. AchE activity is expressed in $\mathrm{mol} / \mathrm{min} / \mathrm{g}$ tissue. The brain samples are prepared according to standard paraffin procedure. Changes related to early-stage Alzheimer's disease were also (un)confirmed by immunohistochemistry used primary antibodies Purified-B-Amyloid, 17-24 Antibody (4G8) diluted 1:2000 (BioLegend, San Diego, CA), Phospho-PHF-Tau (pSer202 + Thr205) Monoclonal Antibody (AT8) diluted 1:500 (Thermo Fisher Scientific, Waltham, MA, USA) and Iba1 diluted 1:250 (Wako Pure Chemical Industries, Japan). Photomicrographs were recorded using a digital camera (AxioCam ERc5s, Zeiss) and processed by a computer program morphometric image analysis (AxioCam ERc5s-ZEN2). The faecal samples were collected from the cages before starting the treatment and on the $3^{\text {rd }}$ and $10^{\text {th }}$ day following the last Lactobacillus administration in triplicates. Faecal samples were stored at $-80^{\circ} \mathrm{C}$ until analysis as described in the next chapter.

\section{Bacterial 16S rRNA sequencing and processing using QIIME}

Faecal samples were collected from rats at the end of the study and used to purify the total genomic DNA using a commercial DNA extraction kit Maxwell DNA Tissue Kit with automated extraction platform, Maxwell ${ }^{\circledR} 16$ Research System instrument (Promega, USA). The final equimolar pool was sequenced on the Illumina MiSeq platform. PCR reactions and 16S sequencing were performed at the Molecular Research LP (MRDNA, Shallowater, Texas USA). The MiSeq instrument (Illumina) was used for sequencing the 16S amplicons following the manufacturer's instructions at MRDNA described by Garcia-Mazcorro et al. (2018) with slight modifications. Raw 16S data were obtained from Illumina's basespace as FASTQ files and analysed using the QIIME 2 pipeline using the procedure as described in the moving pictures tutorial (https://docs.qiime2.org/2018.11/tutorials/moving-pictures/).

\section{PCR -DGGE analysis}

PCR-DGGE analysis was performed according to Leboš Pavunc et al. (2012) with slight modifications in order to check the presence of the $L$ b. plantarum SF9B and $\angle b$. brevis SF9C in faeces of Lactobacillus fed rats. DNA was extracted directly from faecal samples of healthy rats for culture-independent PCR-DGGE analysis, as well as from the bacterial colonies, isolated on MRS agar plates for culture-dependent PCR-DGGE analysis, from faeces of 
healthy rats sampled before feeding (control), and $3^{\text {rd }}$ and $10^{\text {th }}$ day after application of Lactobacillus SF9B and SF9C strains. In both cases, DNA was isolated using Maxwell DNA Cell Kit with automated extraction platform, Maxwell® 16 Research System instrument (Promega, USA). The V2-V3 region of the 16S ribosomal DNA gene of bacteria in the faeces contents or from pure cultures of lactobacilli was amplified with primers HDA1-GC and HDA2. To identify the lactobacilli, recovered from rat faeces, the V2-V3 region of the 16S rRNA gene of the strains was amplified. The amplicons were sequenced using ABI PRISM ${ }^{\circledR}$ 3100-Avant Genetic Analyzer (Applied Biosystems). A search of sequences deposited in the GenBank DNA database was conducted by using the BLAST algorithm. The identities of the isolates were determined based on the highest score.

\section{Statistical analysis}

All the experiments were repeated three times and the results were expressed as means of three independent trials \pm standard deviation (SD). Statistical significance was appraised by one-way analysis of variance. Pairwise differences between the means of groups were determined by the Tukey HSD test for post-analysis of variance pairwise comparisons (http://vassarstats.net/test). Statistical differences between groups were considered significant when $\mathrm{P}$ values were less than 0.05 .

\section{Declarations}

\section{Funding}

This work has been supported by Croatian Science Foundation through the projects IP-2014-09-7009 and IP-201904-2237. Authors also acknowledge financial support of Zagreb University, Croatia. The authors declare that there is no conflict of interest.

\section{Author contributions}

All authors performed the analysis, prepared the manuscript, and contributed to editing and critical reviewing.

\section{Availability of data and materials}

The datasets used and/or analysed during the current study are available from the corresponding author on reasonable request.

\section{Ethics approval and consent to participate}

Not applicable.

\section{Consent for publication}

Not applicable.

\section{Competing interests}

The authors declare that they have no competing interests.

\section{Author details}


[1]Laboratory of Antibiotic, Enzyme, Probiotic and Starter Culture Technologies, Faculty of Food Technology and Biotechnology, University of Zagreb, Pierottijeva 6, Zagreb, Croatia ${ }^{2}$ Laboratory for Biology and Microbial Genetics, Faculty of Food Technology and Biotechnology, University of Zagreb, Pierottijeva 6, Zagreb, Croatia ${ }^{3}$ Department of Animal Physiology, Faculty of Science, University of Zagreb, Rooseveltov trg 6, Zagreb, Croatia ${ }^{4}$ IGA Technology Services srl, via Jacopo Linussio 51, Udine, Italy ${ }^{5}$ Laboratory for Bioinformatics, Faculty of Food Technology and Biotechnology, University of Zagreb, Pierottijeva 6, Zagreb, Croatia

\section{References}

1. Altschul SF, Gish W, Miller W, Myers E W, Lipman D.J. Basic local alignment search tool. J Mol Biol. 1990;215(3):403-404. doi:10.1016/S0022-2836(05)80360-2

2. Anukam KC, Macklaim JM, Gloor GB, Reid G, Boekhorst J, Renckens B et al. Genome Sequence of Lactobacillus pentosus KCA1: Vaginal Isolate from a Healthy Premenopausal Woman. PLOS One. 2013;8(3):e59239. https:/doi:10.1371/journal.pone.0059239

3. Aziz RK, Bartels D, Best AA, DeJongh M, Disz T, Edwards RA. The RAST Server: rapid annotations using subsystems technology. BMC Genomics. 2008;9(75). https:/doi:10.1186/1471-2164-9-75.

4. Banić M, Uroić K, Leboš Pavunc A, Novak J, Zorić K, Durgo K, et al. Characterization of S layer proteins of potential probiotic starter culture Lactobacillus brevis SF9B isolated from sauerkraut. LWT-Food Sci Technol. 2018;93:257-267. https://doi.org/10.1016/j.Iwt.2018.03.054

5. Beganović J, Kos B, Leboš Pavunc A, Uroić K, Jokić M, Šušković J. Traditionally produced sauerkraut as source of autochthonous functional starter cultures. Microbiol Res. 2014;169:(7-8):623-632.

https://doi:10.1016/j.micres.2013.09.015

6. Beganović J, Leboš Pavunc A, Gjuračić K, Špoljarec M, Šušković J, Kos B. Improved sauerkraut production with probiotic strain Lactobacillus plantarum L4 and Leuconostoc mesenteroides LMG 7954. J Food Sci. 2011a;76(2):M124-M129. https://doi:10.1111/j.1750-3841.2010.02030.x

7. Ben Omar N, Abriouel H, Keleke S, Sánchez Valenzuela A, Martínez-Cañamero M, Lucas López et al. Bacteriocinproducing Lactobacillus strains isolated from poto poto, a Congolese fermented maize product, and genetic fingerprinting of their plantaricin operons. Int J Food Microbiol. 2008; 127(1-2):18-25. https://doi:10.1016/j.ijfoodmicro.2008.05.037

8. Chanos P, Mygind T. Co-culture-inducible bacteriocin production in lactic acid bacteria. Appl Microbiol Biot. 2016;100(10):4297-4308. https://doi 10.1007/s00253-016-7486-8

9. Chen P, Miah MR, Aschner M. Metals and neurodegeneration. F1000 Res 5. 2016;366. https:10.12688/f1000research.7431.1

10. Chikindas ML, Weeks R, Drider D, Chistyakov VA, Dicks LMT. Functions and emerging applications of bacteriocins. Curr Opin Biotech. 2017;49:23-28. https://doi 10.1016/j.copbio.2017.07.011

11. Collins FWJ, Mesa-Pereira B, O'Connor PM, Rea MC, Hill C, Ross RP. Reincarnation of Bacteriocins from the Lactobacillus Pangenomic Graveyard. Front Microbiol. 2018;9:1298. https://doi: 10.3389/fmicb.2018.01298t

12. Dicks LMT, Dreyer L, Smith C, van Staden AD. A Review: The Fate of Bacteriocins in the Human GastroIntestinal Tract: Do They Cross the Gut-Blood Barrier? Front Microbiol. 2018;9:2297. https://doi 10.3389/fmicb.2018.02297

13. Diep DB, Straume D, Kjos M, Torres C, Nes IF. An overview of the mosaic bacteriocin pln loci from Lactobacillus plantarum. Peptides. 2009;30:1562-1574. https://doi: 10.1016/j.peptides.2009.05.014 
14. Distrutti E, O'Reilly JA, McDonald C, Ciprian S, Renga B, Lynch MA et al. Modulation of intestinal microbiota by the probiotic VSL\#3 resets brain gene expression and ameliorates the age-related deficit in LTP. PLoS One. 2014;9(9):e106503. https://doi:10.1371/journal.pone.0106503

15. Dobson A, Cotter PD, Ross RP, Hill C. Bacteriocin Production: a Probiotic Trait? Appl Environ Microb. 2012;1-6. https://doi:10.1128/AEM.05576-11

16. Elayaraja S, Annamalai N, Mayavu P, Balasubramanian T. Production, purification and characterization of bacteriocin from Lactobacillus murinus AU06 and its broad antibacterial spectrum. Asian Pac J Trop Biomed. 2014;4:305-311.

17. Fimland N, Rogne P, Fimland G, Nissen-Meyer J, Kristiansen PE. Three-dimensional structure of the two peptides that constitute the two-peptide bacteriocin plantaricin EF. Biochim Biophys Acta. 2008;1784(11):17111719.

18. Frece J, Kos B, Svetec IK, Zgaga Z, Beganović J, Leboš A, Šušković J. Synbiotic effect of Lactobacillus helveticus M92 and prebiotics on the intestinal microflora and immune system of mice. J Dairy Res. 2009;76:98e104.

19. Garcia-Mazcorro JF, Lage NN, Mertens-Talcott S, Talcott S, Chew B, Dowd SE. et al. Effect of dark sweet cherry powder consumption on the gut microbiota, short-chain fatty acids, and biomarkers of gut health in obese db/db mice. PeerJ. 2018;6:e4195. https://doi: 10.7717/peerj.4195

20. Gautier R, Douguet D, Antonny B, Drin G. HELIQUEST: A web server to screen sequences with specific a-helical properties. Bioinformatics. 2008;24:2101-2102.

21. Hartmann HA, Wilke T, Erdmann R. Efficacy of bacteriocin-containing cell-free culture supernatants from lactic acid bacteria to control Listeria monocytogenes in food. Int J Food Microbiol. 2011;146:192-199. https://doi: 10.7717/peerj.4195

22. Hegarty JW, Guinane CM, Ross RP, Hill C, Cotter PD. Version 1. F1000Res. acteriocin production: a relatively unharnessed probiotic trait? 2016;5:2587.B doi: 10.12688/f1000research.9615.1

23. Hynönen U, Kant R, Lähteinen T, Pietilä TE, Beganović J, Smidt H. et al. Functional characterization of probiotic surface layer protein-carrying Lactobacillus amylovorus strains. BMC Microbiol. 2014;14:199. https://doi: 10.1186/1471-2180-14-199

24. Kos B, Beganović J, Jurašić L, Švađumović M, Leboš Pavunc A, Habjanič K. et al. Coculture-inducible bacteriocin biosynthesis of different probiotic strains by dairy starter culture Lactococcus lactis. Mljekarstvo. 2011;61(4):273-282.

25. Kos B, Šušković J, Beganović J, Gjuračić K, Frece J, lannaccone C. et al. Characterization of the three selected probiotic strains for the application in food industry. World J Microbiol Biotechn 2008;24:699-707. https://doi.org/10.1007/s11274-007-9528-y

26. Leboš Pavunc A, Kos B, Beganović J, Uroić K, Bučan D, Šušković J. Antibiotic susceptibility and antimicrobial activity of autochthonous starter cultures as safety parameters for fresh cheese production.

Mljekarstvo.2013;63(4):185-194.

27. Leboš Pavunc A, Beganović J, Kos B, Uroić K, Blažić M, Šušković J. Characterization and Application of Autochthonous Starter Cultures for Fresh Cheese Production. Food Technol Biotechnol. 2012;50(2);1412-151.

28. Ledinski M, Oršolić N, Kukolj M, Odeh D, Mojzeš A, Uroić K, Gačina, L. Analysis of intestine microbiome in the Alzheimer's disease rat model. In: Book of Abstracts of the Annual Meeting of the Croatian Immunological Society with EFIS on Tour Zagreb, Zagreb, 2017, p. 40. 
29. Leenhouts K, Kok J, Venema G. Stability of Integrated Plasmids in the Chromosom Lactococcus lactis. Appl Environ Microb. 1990;56(9):2726-2735.

30. Maldonado-Barragán A, Caballero-Guerrero B, Lucena-Padrós H, Ruiz-Barba JL. Induction of bacteriocin production by coculture is widespread among plantaricin-producing Lactobacillus plantarum strains with different regulatory operons. Food Microbiol. 2013;33:40e47. doi:10.1016/j.fm.2012.08.009

31. Mills S, Ross RP, Hill C. Bacteriocins and bacteriophage; a narrow-minded approach to food and gut microbiology. FEMS Microbiol Rev. 2017;022(41):S129-S153. https://doi: 10.1093/femsre/fux022

32. OJEU. Directive 2010/63/EU of the European Parliament and of the Council on the protection of animals used for scientific purposes. Official Journal of the European Union. 2010;276:33-79.

33. Rogne P, Haugen C, Fimland G, Nissen-Meyer J, Kristiansen PE. Three-dimensional structure of the two-peptide bacteriocin plantaricin JK. Peptides. 2009;30(9):1613-1621.

34. Taverniti V, Stuknyte M, Minuzzo M, Arioli S, De Noni I, Scabiosi C. et al. S-layer protein mediates the stimulatory effect of Lactobacillus helveticus MIMLh5 on innate immunity. Appl Environ Microb. 2013;79:12211231.https://doi: 10.1128/AEM.03056-12

35. Tian, F, Yu L, Zhai Q, Xiao Y, Shi Y, Jiang J, Liu X, Zhao J, Zhang H, Chen W. The therapeutic protection of a living and dead Lactobacillus strain against aluminum-induced brain and liver injuries in C57BL/6 mice PLoS One. 2017;12(4):e0175398. http://doi: 10.1371/journal.pone.0175398

36. Ulusoy HB, Sonmez MF, Kilic E, Caliskan K, Bkaraca B, Kara M. et al. Intraperitoneal administration of low dose aluminium in the rat: how good is it to produce a model for Alzheimer disease. Arch Ital Biol. 2015;153:266-278. https://doi: 10.12871/00039829201543.

37. Uroić K, Novak J, Hynönen U, Pietilä TE, Leboš Pavunc A, Kant R, Šušković J. The role of S-layer in adhesive and immunomodulating properties of probiotic starter culture Lactobacillus brevis D6 isolated from artisanal smoked fresh cheese. LWT-Food Sci Technol. 2016;69:625-632. https://doi.org/10.1016/j.Iwt.2016.02.013

38. van Heel AJ, de Jong A, Song C, Viel JH, Kok J, Kuipers OP. BAGEL4: a user-friendly web server to thoroughly mine RiPPs and bacteriocins. Nucleic Acids Res. 2018;46(W1):W278-W281.

https://doi.org/10.1093/nar/gky383

39. Van Pijkeren JP, O’Tolle PW. Comparative and Functional Genomics of the Genus Lactobacillus. In: Ljungh, Å. and Wadström, T. (eds.) Lactobacillus Molecular Biology: From Genomics to Probiotics. 2013. Caister Academic Press, Norfolk, UK, pp. 59-82. https://doi.org/10.1002/elsc.200990012

40. Yu L, Zhai Q, Liu X., Wang G, Zhang Q, Zhao J, Narbad A, Zhang H, Tian F, Chen W. Lactobacillus plantarum CCFM639 alleviates aluminium toxicity. Appl Microbiol Biotechnol. 2016;100:1891-1900.

https://doi.org/10.1007/s00253-015-7135-7

\section{Tables}

Table 1 Comparison of the antimicrobial activity of Grown Culture (GC) and Cell Free Supernatants (CFS-A - untreated; CFS-B - treated with proteinase K; CFS-C - treated at $100{ }^{\circ} \mathrm{C}$ for 30 min) of two Lactobacillus strains, SF9C and SF9B, separately and combined, against L. monocytogenes ATCC $^{\circledR} 19111^{\mathrm{TM}}$ and $S$. aureus 3048, evaluated by agar spot test for GC and agar well-diffusion method for CFSs 


\begin{tabular}{|c|c|c|c|c|c|c|c|c|}
\hline \multirow{3}{*}{$\begin{array}{c}\text { Lactobacillus } \\
\text { strains }\end{array}$} & \multicolumn{8}{|c|}{ Diameter of the inhibition zone $(\mathrm{cm})$} \\
\hline & \multicolumn{4}{|c|}{ L. monocytogenes ATCC ${ }^{\circledR} 19111^{\mathrm{TM}}$} & \multicolumn{4}{|c|}{ S. aureus 3048} \\
\hline & GC & CFS-A & CFS-B & CFS -C & GC & CFS-A & CFS-B & CFS-C \\
\hline$L b$. & 3,50 & 1,92 & 1,10 & 1,68 & 2,85 & 1,57 & 1,17 & 1,52 \\
\hline plantarum SF9C & $( \pm 0,10)^{\mathrm{az}}$ & $( \pm 0,03)^{\mathrm{ax}}$ & $( \pm 0,00)^{\mathrm{t}}$ & $( \pm 0,03)^{\mathrm{w}}$ & $( \pm 0,13)^{\text {ay }}$ & $( \pm 0,06)^{\mathrm{av}}$ & $( \pm 0,03)^{\mathrm{u}}$ & $( \pm 0,03)^{\mathrm{v}}$ \\
\hline Lb. brevis SF9B & $\begin{array}{c}1,93 \\
( \pm 0,40)^{b z}\end{array}$ & $\begin{array}{c}0,00 \\
( \pm 0,00)^{\mathrm{cx}}\end{array}$ & n.d. & n.d. & $\begin{array}{c}1,35 \\
( \pm 0,05)^{\text {by }}\end{array}$ & $\begin{array}{c}0,00 \\
( \pm 0,00)^{\mathrm{cx}}\end{array}$ & n.d. & n.d. \\
\hline $\begin{array}{c}\text { Combined } \\
\text { SF9C+SF9B }\end{array}$ & $\begin{array}{c}2,57 \\
( \pm 0,06)^{b z}\end{array}$ & $\begin{array}{c}1,72 \\
( \pm 0,03)^{\text {by }}\end{array}$ & n.d. & n.d. & $\begin{array}{c}1,50 \\
( \pm 0,10)^{b x}\end{array}$ & $\begin{array}{c}0,98 \\
( \pm 0,03)^{\mathrm{bw}}\end{array}$ & n.d. & n.d. \\
\hline
\end{tabular}

n.d.- not determined; ${ }^{a b c}$ Different symbol means statistically significant difference $(P<0.05)$ within the same column. ${ }^{\text {tuvwxyz }}$ Different symbol means statistically significant difference $(P<0.05)$ within the same row between the treatments. Statistical analysis was carried out using ANOVA and the results are reported as mean values \pm standard deviation of three independent experiments

Table 2 Competition and exclusion assay of E. coli 3014 and S. Typhimurium FP1 on Caco-2 cells by L. brevis SF9B

\begin{tabular}{|c|c|c|c|c|}
\hline \multirow[t]{2}{*}{ Strain } & \multicolumn{2}{|c|}{$\begin{array}{l}S . \text { Typhimurium FP1 } \\
(\log \mathrm{CFU} / \mathrm{ml})\end{array}$} & \multicolumn{2}{|c|}{$\begin{array}{l}\text { E. coli } 3014 \\
(\log \text { CFU/ml) }\end{array}$} \\
\hline & Competition assay & Exclusion assay & Competition assay & Exclusion assay \\
\hline Cont & $6.825 \pm 0.099$ & $6.825 \pm 0.099$ & $8.517 \pm 0.157$ & $8.517 \pm 0.157$ \\
\hline Lb. brevis & $5.613 \pm 0.135^{*}$ & $4.708 \pm 0.014^{* *}$ & $6.393 \pm 0.101^{* *}$ & $6.308 \pm 0.194^{* *}$ \\
\hline
\end{tabular}

Statistical analysis was carried out using ANOVA and the results are reported as mean values of three separate experiments \pm standard deviation. Asterisks indicate significant differences of adhered $E$. coli 3014 and $S$. Typhimurium FP1, without (control) and with the addition of the $L b$. brevis SF9B strain compared to control at different levels: ${ }^{* *} \mathrm{P}<0.01,{ }^{*} \mathrm{P}<0.05$

Table 3 Bacterial strains used in this study

\begin{tabular}{lll}
\hline Bacterial strain & Cultivation conditions & Reference \\
\cline { 2 - 3 } Lb. brevis SF9B & MRS, $37^{\circ} \mathrm{C}$, microaerophilic & Banić et al. (2018) \\
Lb. plantarum SF9C & $\mathrm{MRS}, 37^{\circ} \mathrm{C}$, microaerophilic & This study \\
E. coli 3014 & $\mathrm{BHI}$ broth, $37^{\circ} \mathrm{C}$, aerobic & CIM-FFTB* \\
S. Typhimurium FP1 & $\mathrm{BHI}$ broth, $37^{\circ} \mathrm{C}$, aerobic & CIM-FFTB \\
L. monocytogenes ATCC ${ }^{\circledR} 1911^{\mathrm{TM}}$ & $\mathrm{BHI}$ broth, $37^{\circ} \mathrm{C}$, aerobic & ATCC** \\
S. aureus 3048 & $\mathrm{BHI}$ broth, $37^{\circ} \mathrm{C}$, aerobic & CIM-FFTB
\end{tabular}

*CIM-FFTB - Culture collection of the Laboratory of Antibiotic, Enzyme, Probiotic and Starter Culture Technologies, Faculty of Food Technology and Biotechnology, University of Zagreb; **ATCC - American Type Culture Collection 
Subsystem Category Distribution

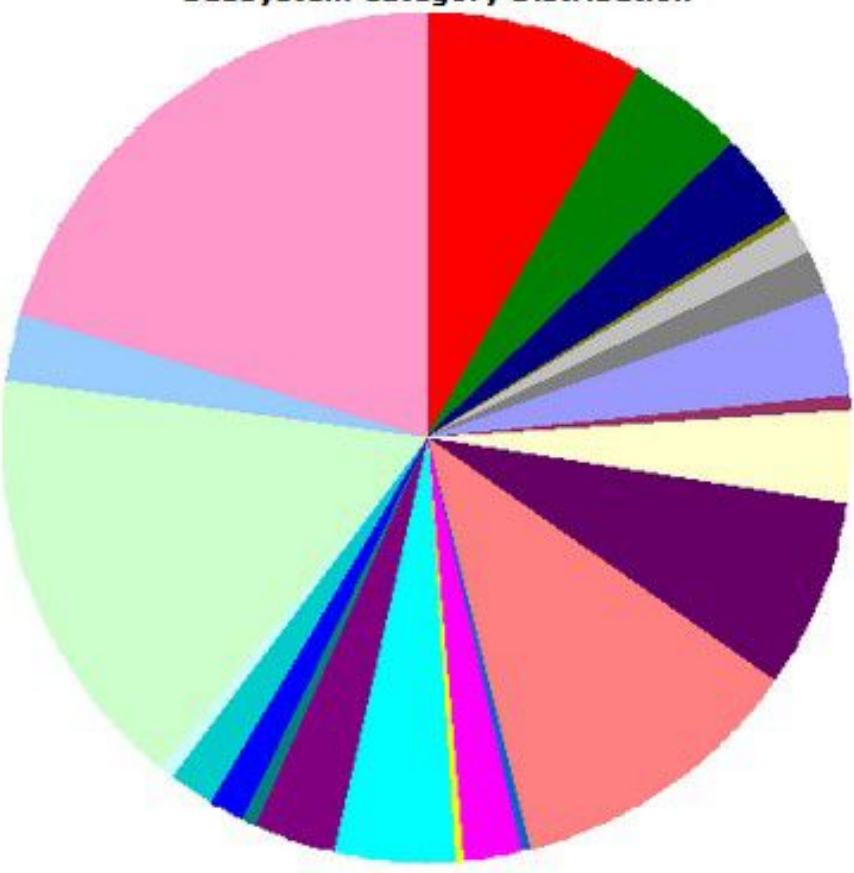

Subsystem Feature Counts

(1- Cofactors, Vitamins, Prosthetic Groups, Pigments (101)

10 Cell Wall and Capsule (53)

- Virulence, Disease and Defense (40)

(9) Potassium metabolism (5)

- Photosynthesis (0)

(1) Miscellaneous (17)

- Phages, Prophages, Transposable elements, Plasmids (18)

(9. Membrane Transport (49)

G. Iron acquisition and metabolism (5)

(1) RNA Metabolism (44)

9 Nucleosides and Nucleotides (87)

(1) Protein Metabolism (136)

$\square$ Cell Division and Cell Cycle (4)

G Motility and Chemotaxis (0)

Regulation and Cell signaling (28)

๑ Secondary Metabolism (4)

(1) DNA Metabolism (56)

(1) Fatty Acids, Lipids, and Isoprenoids (36)

(1) Nitrogen Metabolism (0)

(1- Dormancy and Sporulation (6)

G Respiration (17)

- Stress Response (21)

9 Metabolism of Aromatic Compounds (8)

(1) Amino Acids and Derivatives (194)

$\square \quad$ Sulfur Metabolism (3)

(1) Phosphorus Metabolism (33)

(9) Carbohydrates (238)

Figure 1

Distribution of Lb. plantarum SF9C subsystem gene functions. The complete genome sequence Lb. plantarum SF9C of was annotated using the Rapid Annotation System Technology (RAST) server. The pie chart showed the count of each subsystem feature and the subsystem coverage 


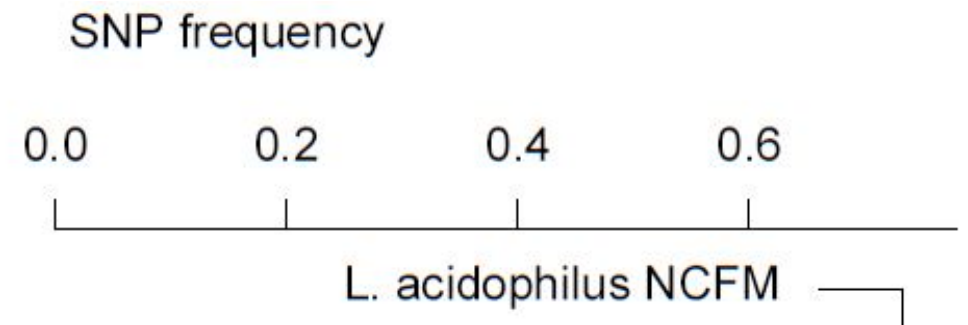

L. plantarum WCFS1

L. plantarum NC8

L. plantarum $\mathrm{RI}-113$

L. plantarum B21

L. plantarum BDGP2

L. plantarum SF15

L. plantarum SF9C

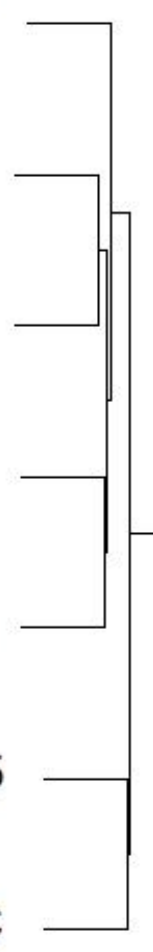

L. brevis SF15B

L. brevis ATCC 367

L. brevis SF9B

Figure 2

Single Nucleotide Polymorphism (SNP) based hierarchical clustering. Clustering of multiple Lactobacillus genomes based on SNP frequency, plotted on the y axis. SNP frequency is "number of bases divided by bases aligned" 
Gene names

Predicted promoters

Predicted terminators

Show or hide small ORFS

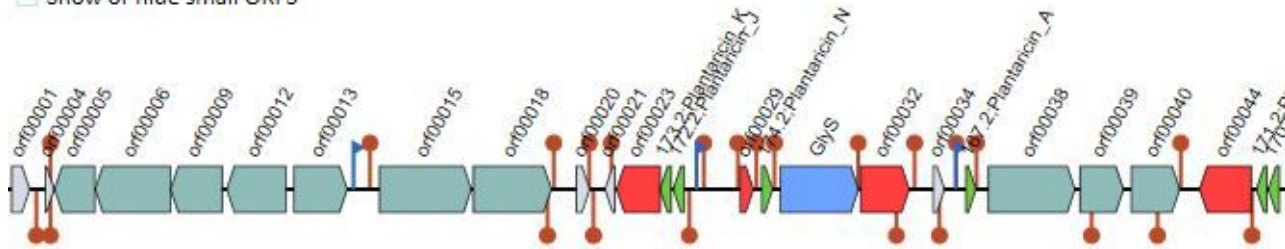

$\square$ Regulation

$\square$ Transport \& Leader cleavage

$\square$ Protease

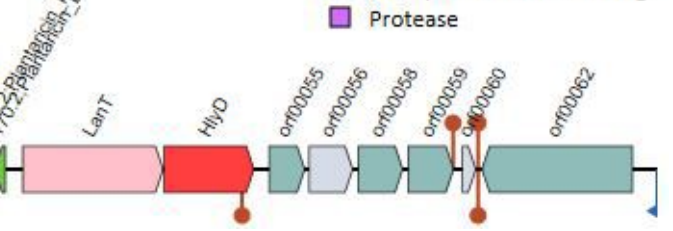

Figure 3

Genetic map of the plantaricin gene cluster in Lb. plantarum SF9C strain
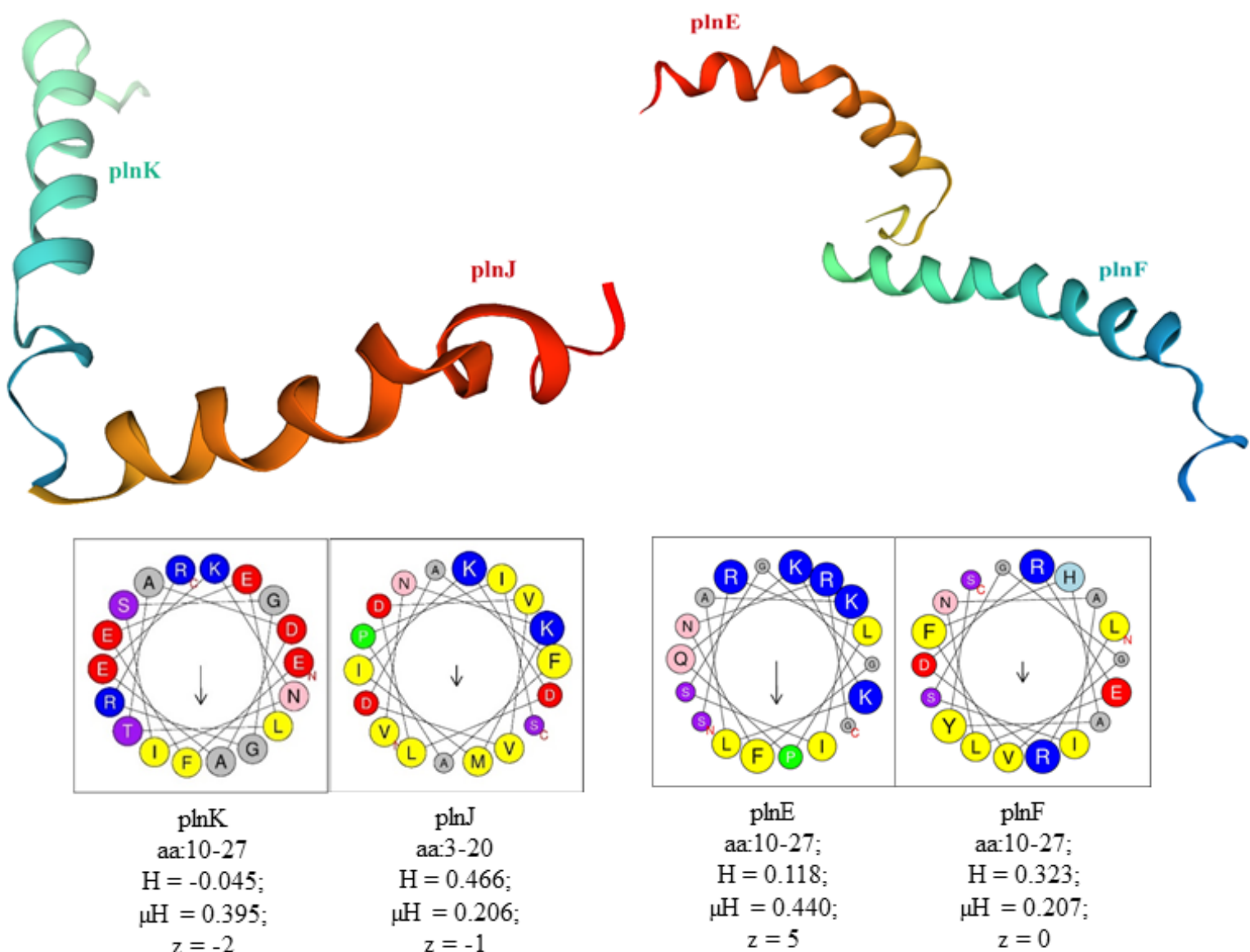

$\mathrm{plnK}$

$z=-2$

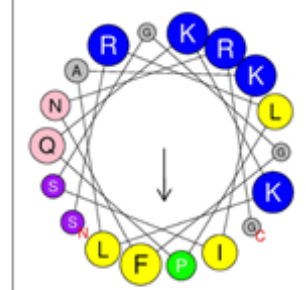

$\mathrm{pln} E$

aa: 10-27;

$\mathrm{H}=0.118$;

$\mu \mathrm{H}=0.440 ;$

$z=5$

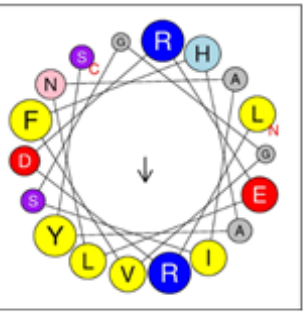

$\mathrm{pln} F$

aa: 10-27;

$\mathrm{H}=0.323$;

$\mu \mathrm{H}=0.207$;

$\mathrm{z}=0$

\section{Figure 4}

Homology-based 3D structures of SF9C two-peptide plantaricins predicted by the SWISS-MODEL Homology Modelling and helical wheel projections analysed by HeliQuest of the peptides PInJ/K and PInE/F. $\mathrm{H}$ and $\mu \mathrm{H}$ are the mean hydrophobicity and the hydrophobic moment calculated by HeliQuest, respectively. The net charge (z) was calculated at $\mathrm{pH}=7.4$, under the assumption that histidine is neutral and that the $\mathrm{N}$-terminal amino group and the 
C-terminal carboxyl group of the sequence are uncharged. aa is the amino acid residues. The one letter code for amino acids is used

a)

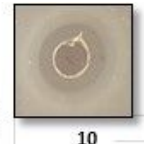

b)
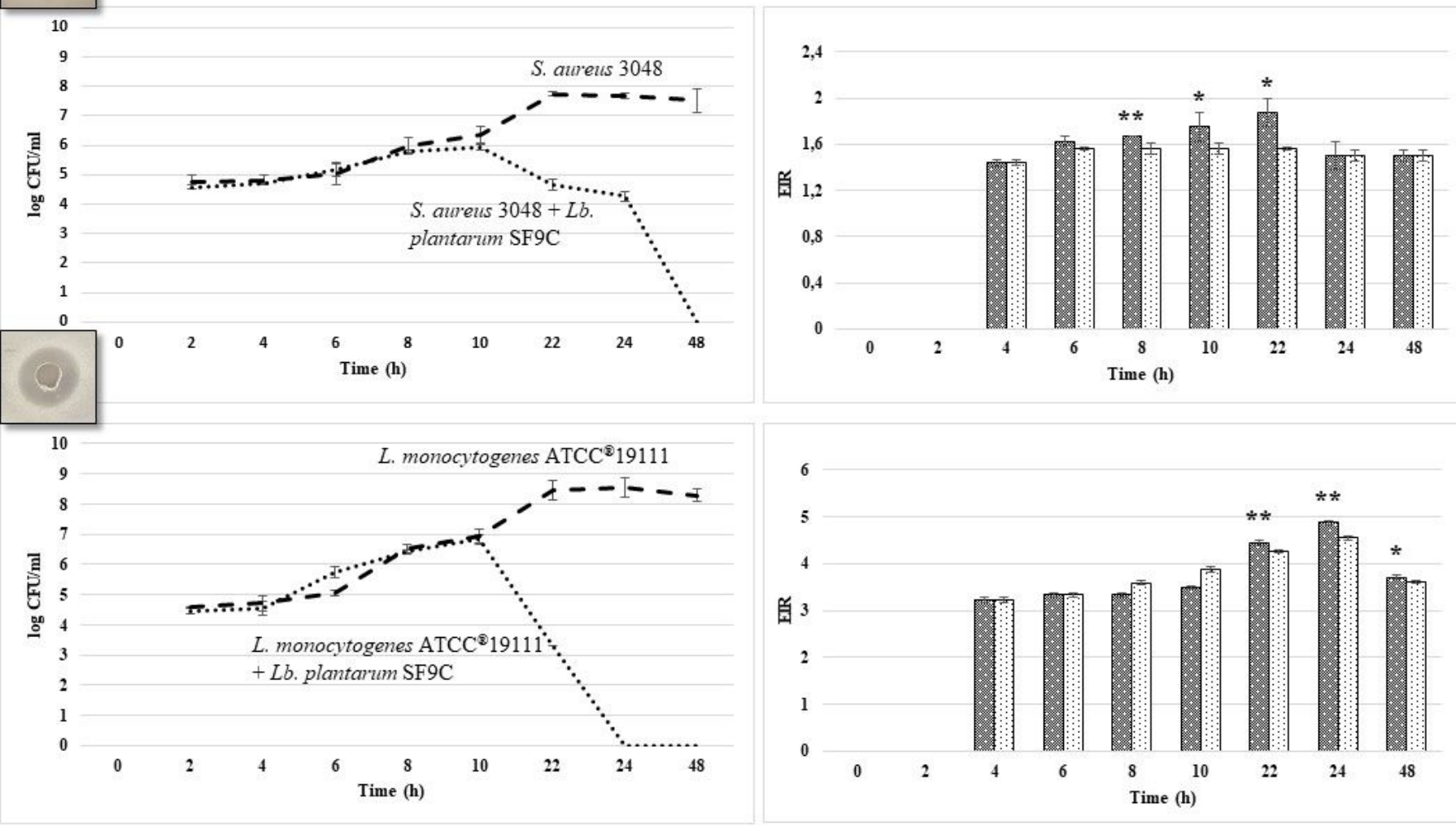

Figure 5

The growth curves of the test microorganisms: a) S. aureus 3048 and B) L. monocytogenes ATCC ${ }^{\circledR} 19111^{\text {TM }}$ without (a) or with (*) Lb. plantarum SF9C cocultivation. Growth of Lb. plantarum SF9C was not influenced by incubation with test microorganisms (data not shown). The right side of the figure shows the bars representing EIR of test microorganisms, resulting from the antimicrobial activity of the Lb. plantarum SF9C after the growth in coculture with: A) S. aureus 3048 and b) L. monocytogenes ATCC ${ }^{\circledR} 19111^{\mathrm{TM}}$ (1), respectively, and after the growth of SF9C alone ( ) obtained by agar spot test. Each value shown is the mean \pm SD. Asterisks indicate statistically significant differences of EIR of test microorganisms obtained by the Lb. plantarum SF9C after the growth in coculture with test microorganisms and alone, at the same incubation time: ${ }^{*} \mathrm{P}<0.05,{ }^{*} \mathrm{P}<0.01$ 


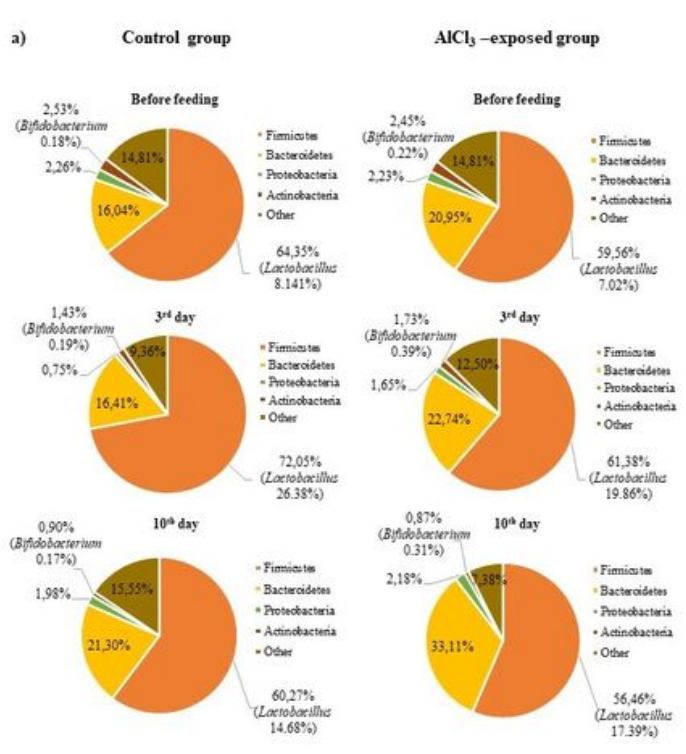

b)

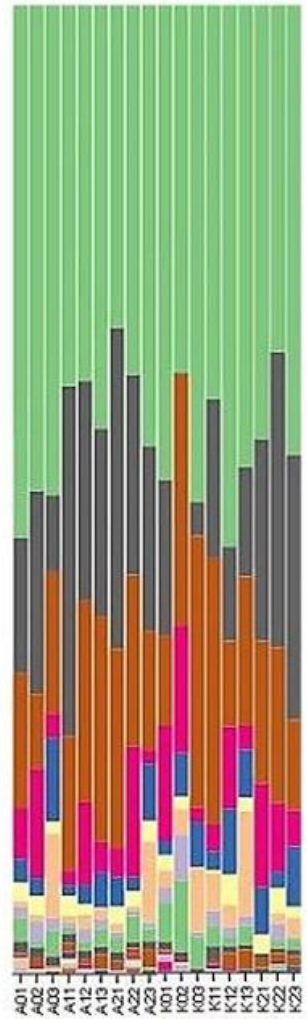

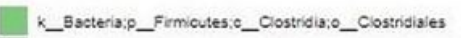

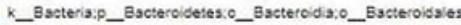

k_Bacteria:P_Fimieutes:0_Esoilio_Lastobscills/es

k_Arehaes:p_Euryarchaeota:0_Methanobasteria; _ Methanobacteriales

k_Eacteria:P_TM7:0_TM7.3:0_CW040

K_Easteria:p_Protecbactoria:o_Deltaproseobacteria:o_Desultovibrionales

K_Bacteria:P_Tenericuses:O_Moliouses:o_RF38

k_Bacteria:P_Actnobactena:c_Conibbacteria:o_Conobacteriales

K_Eactena:P_Firmoutes:o_Eacolico_Tunobacterales

K_Bacteria:0_Firmicutes:o_Erysipelotrichio_Eysipelotrichales

K_Bacteria:P_Spirochatetes:C_Sprochse:es:0_Spircenatiales

K_Escteris:P_Aetinobacteris.c_Actinobacteris.0_Bisdobacteris/es

K_Bacteris:P_Prosecoseteria;0_Betsproteobatteria:0_Burkholderiales K_Eacteria:P_Cyanobacteria:c_4COd.2:0_YS2

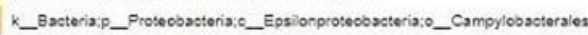

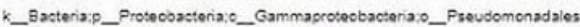

K_Eacteria:P_Protecosacteria; __Aphaproteobacteriaj_RF32

k_Bacteria:p_Eacteroidetes__-

k_Eacteria:p_Eusimicrobia:_Elusimicrobia:0_Elusimcrobiales

k_Bacteria:P_Firmicutes:c_Eacilico_Sacilales

k_ 9acteria:P_Actinoo3ctenia:c_Actinobacteria:O_Actnomycetales K_Bacteris;p_Proteobscteris,0_Gammagroteobscteris,o_Enterobscteriales

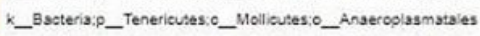

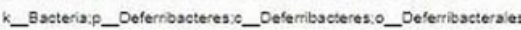

k_Bacteria:-

\section{Figure 6}

a) The four most abundant phyla detected in the faecal microbiota of control and AICl3-exposed rats, both fed with Lb. plantarum SF9C and Lb. brevis SF9B b) The distribution of the bacterial classes in the faeces of control (K) and AlCl3-exposed rats (A), before application (0), and 3rd day (1), and 10th day (2) after application of SF9B and SF9C strains

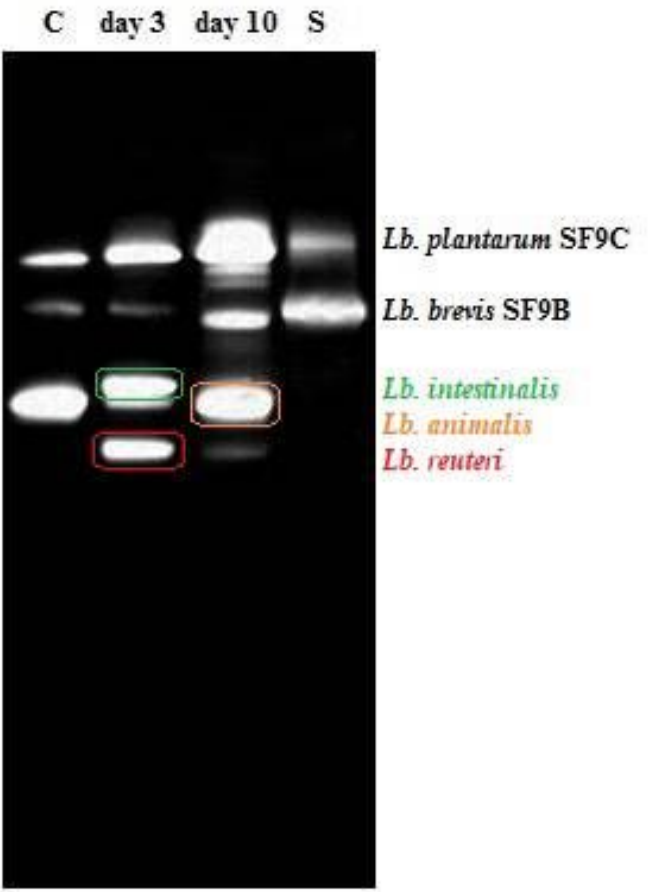




\section{Figure 7}

PCR-DGGE analysis of 16S DNA fragments generated with the universal bacterial primers HDA1 and HDA2 from the pooled DNA samples of the Lactobacillus species, isolated on MRS agar from faecal samples of rats fed with Lb. plantarum SF9C and Lb. brevis SF9B. Lanes: C - rats before application of SF9C and SF9B strains; day 3 - 3th day after application of SF9C and SF9B strains; day 10 - 10th day after application of SF9C and SF9B strains, S- the ladder of sequences from the pure cultures of SF9C and SF9B strains, respectively. Bands indicated by the symbols were excised and after amplification subjected to sequencing

\section{Supplementary Files}

This is a list of supplementary files associated with this preprint. Click to download.

- Graphicalabstract.jpg

- SupplementarytableS1.docx

- SupplementaryFigure1.jpg 